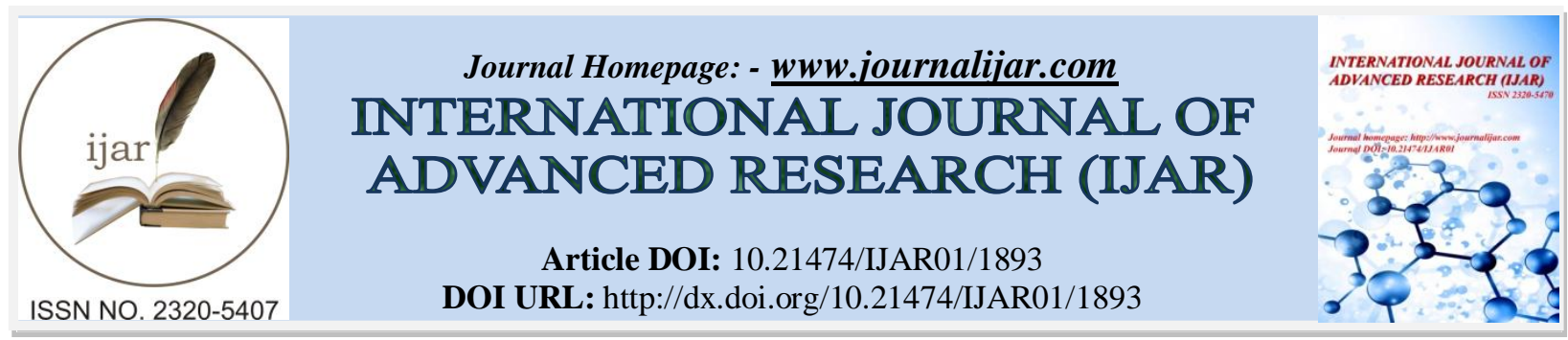

RESEARCH ARTICLE

\title{
ASSESSMENT OF SOME IMMUNOLOGICAL ASPECTS IN IMMUNODEFICIENCY PATIENTS WITH BACTERIAL SKIN INFECTION.
}

\author{
Huda Mohammed Kadhim', Wafaa Sadeq Al-Wazni ${ }^{2}$ and Zuhair Hamid Aboud ${ }^{2}$. \\ 1. Out from the master's thesis for the first researcher. \\ 2. Karbala University, College of Science, Department of biology
}

\section{Manuscript Info}

Manuscript History

Received: 13 August 2016

Final Accepted: 16 September 2016

Published: October 2016

Key words:-

Immunodeficiency, bacterial skin infection, immunological aspects

\section{Abstract}

The main objective of the study was to determine the difference in immune response between the two groups of patients suffering from bacterial skin infections, where the first group included 50 Immunodeficiency patients while the second group was 50 non immunodeficiency patients.

The first step of this study consisted of isolating the bacterial species responsible for skin infections in the two groups were isolated 43 bacterial isolation distributed among the 28(65.1\%) isolates of the first group and $15(34.9 \%)$ isolates of the second group. Staphylococcus aureus Psudomonase auregenosa had the highest isolation rate, reaching $24(55 \%)$ and $10(23.8 \%)$ respectively, in addition to that the highest proportion of bacterial isolate has been recorded in the cancer patients10 (35.7\%) than in the rest Immunodeficiency cases.

There is no significant increase in the total number of white blood cells with marked rise in neutrophil cells only in immunodeficiency patients groups with skin infection compared with immunodeficiency patients groups without skin infection as well as with the control group and there is a decrease in the level of C3 in most studied groups except cancer patients compared to control group. While a concentration of $\mathrm{C} 4$ showed no significant increase in both normal and immunodeficiency immune system patients with skin infections except kidney failure patients compared to control group.

There was significant increase in the level of IL- 33 in immunodeficiency patients with skin infection compared to other patients groups, especially patients with diabetes and renal failure, While there was clearly a significant decrease in the level of IL-27 in the studied groups compared to the control group, but increased in immunodeficiency patients with skin infection compared with normal immune system and skin infections patients as well as the present results showed that there is a clear rise in the level of TNF$\alpha$ in the serum of all patients groups under study compared to the control. 


\section{Introduction:-}

Immunodeficiency casus is define as situation in which weaken the ability of immune system to prevent the infection occurs by foreign microorganism because defect in the cellular (macrophages and T-lymphocytes and Blymphocytes) or humeral (complement and antibodies) immune system components either because of a genetic defect in patients since birth as a result of special genetic mutations causing a state of the primary immunodeficiency or occurs as a result of infection by a specific virus or exposure to one of inhibitors immune system inhibitors such as treatments with chemical drugs or development of chronic disease such as, diabetes, kidney failure, severe burns and other causes that make patient susceptible to serious complications threaten the patient life in particular and causing a state of secondary immunodeficiency. The severity of these complication depends on the sensitivity of the immune system components and the degree of dysfunction [Buckley,2000;Vihinen,2005].Many of the immunodeficiency patient are often have abnormal skin thing that makes them more susceptible to various infections, when the skins regard the largest organ in the human body and it is the main site of interaction with the external environment as well as represented the first line of defense and immunologically barrier against invading microbes that can enter through cuts, scratches or burns that occur in it, which make the skin favorable environment for the growth and multiplication of bacteria that have come from either external or internal especially with the presence of various immunocompromized cause (primary and secondary), as well as facilitate the invasion of pathogen into the body causes systemic diseases (Sanin et al.2015; Chung et al.,2008).

Many pathogenic bacteria such as $S$. aureus and $P$. aeruginosa posses multiple virulence factors there for able to cause infections in wounds burn, wounds operations and catheters. These bacterial species are common isolated from skin infection especially in patient with immunodeficiency causes because these genes spread largely in the hospital environment (Todar,2002) and some time several bacterial species exist naturally in healthy people as found in the gastrointestinal tract, mouth and vagina which may cause skin infections because possess virulence factors that enable them to invade the host tissue, especially damaged one, which led to increased incidence of infections, especially in immunodeficiency patients (Senna etal.,2012; Yang, 2003)Who suffer from imbalance of the immune system components such as different in total and differential white blood cells count, which is in turn an initial indication of the immune status of the patient and a first cellular immune are responsible to prevent the crossing of the invasion bacteria skin barrier of the human body (Brooks,2008). There are decline in the number of white blood cells in immunocompromized patient such as renal failure and thing that increase the chance of the development of infection in the sites of wounds and burns damage, those infection that lead to a slight increase in the WBC count especially neutrophil cells in these patients because the aggravation of the bacterial infection in the host. These factors combined may be affecting on the other component of the humeral and cellular immune system where the Langerhans cells in collaboration with T-lymphocytes and neighboring Keratinocytes in the skin secrete many Cytokines, which are small protein with low- molecular weight and have an important role in regulating the immune response of the body and which are divided into two main types pro and anti-inflammatory cytokines in addition to its important role in various inflammatory conditions (Yoshida etal.,2009).

The level of these cytokines gives important indications about the immunocompromized cause and the presence of infection in host body. When burn or deep wound or cuts occur in the skin the keratinocytes cells stimuli to secrete many of the pro -inflammation cytokines such as Interleukin - 1 family, which plays an important role in regulating the immune response, also expanding the inflammatory and immune response by urging keratinocytes cells to release further amount of IL- 1 and also stimulating the pro-inflammatory cytokines such as IL-6, IL - 8, TNF- , IL -33 and IL-12 (Liu et al 2003; Biffle et al.,1996). There for share lymphocytes, phagocytes cell with cytokines and complement proteins in regulating the immune response and eliminate the pathogen inside the body (Roitt \& Rabson,2000)

The percentage of bacterial skin infection increased recently among immunocompromized patients undergo from burns, wounds, diabetes, cancer and kidney failure in Karbala province so present study aimed to find a relationship between the immune changes associated with the immunocompromized state and severity of bacterial skin infection in these patients. 


\section{Methods:-}

\section{Patients:-}

This study was included 150 patients (50 immunodeficiency patient, 50 immunodeficiency patient with skin infection and 50 normal immune system patients with skin infection) with age ranged between 1-80 years and from both sex, attending AL-Hussein Teaching hospital in Karbala Province.

\section{Blood sample:-}

Blood sample $5 \mathrm{ml}$ were taken from all patient and from 16 healthy person as control group under septic conditions and divided into two part $3 \mathrm{ml}$ were left to 10 minutes for clotting before being centerfication at 6000rpm to separate the serum and this serum samples were kept under frozen at $-20 \mathrm{C}^{\circ}$ in appendrof tubes until use. While $2 \mathrm{ml}$ were kept in EDTA tube until used in determine WBC counts.

\section{Skin swabs:-}

The skin swabs were collecting from 100 patients with skin infections (50 immunodeficiency patients and 50 normal immune system patients). Then the swabs directly cultured on general and differential media for bacterial isolation.

\section{Identification of isolated bacteria:-}

The bacterial colony were taken from primary positive culture on general and differential media were identified depending on its morphological and biochemical characteristic according to method described by Collee $e t$ al (1996), and Baron et al.(1990).Then the diagnosed bacteria were confirmed by Api20 E \& Api staph system(accomplished according to manufacturer's instrument) and then by Vitek method.

\section{Immunological Tests:-}

Immunological tests included the following:

\section{Total \& Differential count of leucocytes.}

The full count of blood (CBC) factory by company Roby USA was used to determine the total and differential white blood cells count and this factory is widely used in medical laboratories.

\section{Estimation the concentration of IL-27, IL-33 and TNF- $\alpha$ in serum of study groups.}

The level of IL-27, IL-33 and TNF- $\alpha$ were determined by using kits processed instructions from company Elabscience (Ltd ) and according to instruction company processed by using the ELISA technique.

\section{Estimation the concentration of complement proteins ( $\mathrm{C} 3$ and $\mathrm{C4}$ ) in serum of study groups.}

The concentration of complement components (C3 and C4) in the serum were determined by kit processed from Company Easy RID (Italy) by using single radial immunodiffusion method described by Mancini et al (1965).

\section{Statistical Analysis:-}

Statistical analysis was performed of data using excel program in the computer where the mean value, standard deviation and Statistical significant of difference LSD and between two means were calculated at the level of probability of 0.05 .

\section{Results and Discussion:-}

Percentage of bacterial infection:-

The results of this study showed presence of bacterial growth in only 43 specimen of the total skin swabs. Where the number of bacterial isolates for a group of immunodeficiency patients is the highest $28(65.1 \%)$ compared to patients with normal immune system 15 (34.9\%) as shown in Table (1): 
Table 1:- Percentage of isolated bacteria from skin infection of study groups.

\begin{tabular}{|c|c|c|c|c|c|c|c|c|}
\hline \multirow{2}{*}{\multicolumn{2}{|c|}{ Study groups }} & \multicolumn{6}{|c|}{ Bacterial isolates } & \multirow{2}{*}{$\begin{array}{l}\text { Total } \\
\text { bacterial } \\
\text { isolate }\end{array}$} \\
\hline & & S.aureus & CNS & $\begin{array}{l}\text { P.aerugin } \\
\text { os }\end{array}$ & E.coli & $\begin{array}{l}\text { K.pneumon } \\
\text { iae }\end{array}$ & $\begin{array}{l}\text { S.marcesce } \\
n s\end{array}$ & \\
\hline \multirow{5}{*}{\begin{tabular}{l}
\multicolumn{2}{l}{ Immunodeficie } \\
ncy patients \\
with rkin \\
infection \\
patients
\end{tabular}} & $\begin{array}{l}\text { Cancer } \\
n=13\end{array}$ & 7 & 0 & 2 & 1 & $\overline{\mathbf{0}}$ & $\mathbf{0}$ & $\begin{array}{l}(35.7 \%) \\
10\end{array}$ \\
\hline & $\begin{array}{l}\text { Diabet } \\
\text { es } \\
n=11\end{array}$ & 2 & $\mathbf{0}$ & $\mathbf{0}$ & $\mathbf{0}$ & $\mathbf{1}$ & $\mathbf{0}$ & $3(10.7 \%)$ \\
\hline & $\begin{array}{l}\text { kidne } \\
\mathbf{y} \\
\text { failur } \\
\mathrm{e} \\
\mathrm{n}=11\end{array}$ & 4 & 1 & 1 & $\mathbf{0}$ & $\mathbf{0}$ & $\mathbf{0}$ & $6(21.4 \%)$ \\
\hline & $\begin{array}{l}\text { Burns } \\
n=15\end{array}$ & 1 & 0 & 6 & $\mathbf{0}$ & 1 & 1 & $9\left(32.1^{\%}\right)$ \\
\hline & Total & $14(50 \%)$ & $\begin{array}{l}\%) \\
1(3.5\end{array}$ & $\begin{array}{l}\%) \\
9(32.1\end{array}$ & $\begin{array}{l}(3.5 \%) \\
1\end{array}$ & $2(7.1 \%)$ & $1(3.5 \%)$ & $\begin{array}{l}(65.1 \%) \\
28\end{array}$ \\
\hline \multicolumn{2}{|c|}{$\begin{array}{l}\text { Normal immune system } \\
\text { with skin infection } \\
\text { patients } \\
\text { n=50 }\end{array}$} & $\begin{array}{l}(66.6 \%) \\
10\end{array}$ & $0(0 \%)$ & $1(6.6 \%)$ & $\begin{array}{l}(6.6 \%) \\
1\end{array}$ & $3(20 \%)$ & $(0 \%)$ & $\begin{array}{l}\text { \%) } \\
15(34.9\end{array}$ \\
\hline \multicolumn{2}{|l|}{$\begin{array}{l}\text { Total } \\
\mathrm{N}=100\end{array}$} & $\begin{array}{l})_{24(55 \%} \\
\text { 24 }\end{array}$ & $\begin{array}{l}(2.3 \%) \\
2\end{array}$ & $\begin{array}{l}(23.8 \%) \\
10\end{array}$ & $\begin{array}{l}(4.6 \%) \\
2\end{array}$ & $5(11.6 \%)$ & $1(1.3 \%)$ & 43 \\
\hline
\end{tabular}

The cancer patients is the highest in the bacterial isolation $10(\%$ 35.7) and $S$. aureus bacteria were higher isolate bacteria $24(55 \%)$ in studied groups (immunodeficiency $14(50 \%)$ and normal immune system patients10 $(66.6 \%)$.These results approached with result of several studies and these bacteria are more common and widespread cases of inflammation in wounds and burns because its ability to spread and invade tissue damage and cause skin lesions (Oznmba and Jibum, 2000). While the reason for repeat P. aeruginosa bacteria in patients is their ability to invade damage tissues then cause septicemia, particularly in immunodeficiency patients (Jawetz et $a l ., 1998)$.As well as its ability to grow at room temperature and resist several types of detergents and antibiotics. In addition, these bacteria have several types of virulence factors and short generation time (Oznmba and Jibum, 2000).

\section{Immunological Parameter:-}

Total \&Differential count of WBC:-

The results shown in table (2) revealed that the total number of white blood cells (Total WBC) in immunodeficiency patients with skin infection such as cancer, diabetes, kidney failure and burns patients reaching to $6.57,6.58,7.14,7.09 \times 10^{3} / \mathrm{ml}$ respectively, compared with the number of WBC in immunodeficiency patient without a skin infection , which reached to 5.36,6.17, 6.045, $4.85 \times 10^{3} / \mathrm{ml}$, respectively, While arrived to $6.5 \times 10^{3} / \mathrm{ml}$ in normal immune system patients with a skin infected which was approached to the WBC count in control group $6.45 \times 10^{3} / \mathrm{ml}$.

The results of the differential count of white blood cells showed the number of Neutrophils cells increased significantly in immunodeficiency patients (Cancer $6.31 \times 10^{3}$, Diabetes $5.48 \times 10^{3}$, Renal failure $6.321 \times 0^{3}$ and Burn $\left.6.241 \times 0^{3}\right)$ with skin infection compared to other studied groups. The results also note there is a significant rise in the number of lymphocytes in immunodeficiency patients with a skin infection compared to the immunodeficiency patients without a skin infection and natural immune system patients with a skin infected, where that taking immunosuppressive drugs will reduce the activity of lymphocytes cell which belonging to the rise in the case of development skin injury (House and Descotes, 2007).The high blood sugar will affect on the activity of neutrophil blood cell in each of the chemotactic, attachment and phagocytes stage because its effect on the $\mathrm{pH}$ of the blood ,which in turn increases the production of white blood cells, especially in the advanced stages of diabetes, which is characterize by the production of ketone bodies and development several physiological changes (Xu et 
al.,2013).The increase in the number of white blood cells in patients with burns may be due to the access of developing germ into the bloodstream, where migration for some white blood cells such neutrophils and monocytes to the inflammation site and carry out its functions who is under the influence of humoral components such as complement protein and cytokines that are characterized by their ability to differentiation and activity of these cells (Douwes et al., 2002;Ennis,2006).

Table 2:- Total and differential numbers of white blood cells in all studied groups.

\begin{tabular}{|c|c|c|c|c|c|c|c|c|c|c|}
\hline \multirow[t]{2}{*}{$\begin{array}{l}\text { Study } \\
\text { groups }\end{array}$} & \multirow[t]{2}{*}{$\begin{array}{l}\text { Contr } \\
\text { ol }\end{array}$} & \multirow{2}{*}{$\begin{array}{l}\text { Norma } \\
\text { l } \\
\text { immun } \\
\text { e } \\
\text { system } \\
\text { patient } \\
\text { s with } \\
\text { skin } \\
\text { infectio } \\
\text { n }\end{array}$} & \multicolumn{4}{|c|}{$\begin{array}{l}\text { Immunodeficiency patients with Skin } \\
\text { infection }\end{array}$} & \multicolumn{4}{|c|}{$\begin{array}{l}\text { Immunodeficiency patients without } \\
\text { skin infection }\end{array}$} \\
\hline & & & Cancer & Diabetes & $\begin{array}{l}\text { kidney } \\
\text { failure }\end{array}$ & Burns & Cancer & $\begin{array}{l}\text { Diabete } \\
\text { s }\end{array}$ & $\begin{array}{l}\text { kidney } \\
\text { failure }\end{array}$ & Burn \\
\hline $\begin{array}{l}\text { Total } \\
\text { WBC } \\
\text { Mean+SD }\end{array}$ & $\begin{array}{l}6.45 \\
\pm 0.7\end{array}$ & $6.5 \pm 0.5$ & $6.57 \pm 0.6$ & $6.58 \pm 0.6$ & $7.14 \pm 0.3$ & $7.09 \pm 0.2$ & $\begin{array}{l}5.36 \pm 0 . \\
9\end{array}$ & $\begin{array}{l}6.17 \pm 0 . \\
5\end{array}$ & $\begin{array}{l}6.04 \pm 0 . \\
4\end{array}$ & $4.86 \pm 1.4$ \\
\hline $\begin{array}{l}\text { Neutrophi } \\
\text { ls } \\
\text { Mean } \pm \text { SD }\end{array}$ & $\begin{array}{l}4.89 \pm 1 \\
0\end{array}$ & $\begin{array}{l}6.21 \pm 0.5 \\
*\end{array}$ & 6.24 \pm 0.6 & $\begin{array}{l}6.32 \pm 0.5 \\
*\end{array}$ & $\begin{array}{l}\mathbf{5 . 5 8} \pm \mathbf{0 . 6} \\
*\end{array}$ & $\begin{array}{l}6.31 \pm 0.5 \\
*\end{array}$ & $\begin{array}{l}5.61 \pm 1 . \\
1\end{array}$ & $\begin{array}{l}4.68 \pm 0 . \\
4\end{array}$ & $\begin{array}{l}3.86 \pm 0 . \\
7\end{array}$ & $4.43 \pm 0.5$ \\
\hline $\begin{array}{l}\text { Eosinophil } \\
\text { Mean } \pm \text { SD }\end{array}$ & $\begin{array}{l}0.25 \pm 0 . \\
10\end{array}$ & $\begin{array}{l}\mathbf{0 . 2} \pm \mathbf{0 . 0 3} \\
* *\end{array}$ & $\begin{array}{l}0.18 \pm 0.0 \\
2\end{array}$ & $\begin{array}{l}0.27 \pm 0.0 \\
8\end{array}$ & $\begin{array}{l}0.19 \pm 0.0 \\
6\end{array}$ & $\begin{array}{l}0.25 \pm 0.0 \\
4\end{array}$ & $\begin{array}{l}0.1 \pm 0.0 \\
9\end{array}$ & $\begin{array}{l}0.18 \pm 0 . \\
13\end{array}$ & $\begin{array}{l}0.12 \pm 0 . \\
05\end{array}$ & $0.1 \pm 0.05$ \\
\hline $\begin{array}{l}\text { Basophile } \\
\text { Mean } \pm \text { SD }\end{array}$ & $\begin{array}{l}0.24 \pm 0 . \\
04\end{array}$ & $\begin{array}{l}0.31 \pm 0.0 \\
7\end{array}$ & $\begin{array}{l}0.23 \pm 0.0 \\
5\end{array}$ & $\begin{array}{l}0.26 \pm 0.0 \\
6\end{array}$ & $0.2 \pm 0.05$ & $\begin{array}{l}0.21 \pm 0.0 \\
3\end{array}$ & $\begin{array}{l}0.24 \pm 0 . \\
15\end{array}$ & $\begin{array}{l}\mathbf{0 . 1 3} \pm \mathbf{0} \\
1\end{array}$ & $\begin{array}{l}0.23 \pm 0 . \\
3\end{array}$ & $\begin{array}{l}0.26 \pm 0.0 \\
55\end{array}$ \\
\hline $\begin{array}{l}\text { Lymphocy } \\
\text { tes } \\
\text { Mean } \pm \text { SD }\end{array}$ & $\begin{array}{l}2.2 \pm 1.1 \\
7\end{array}$ & $\begin{array}{l}2.98 \pm 0.4 \\
4 *\end{array}$ & $\begin{array}{l}3.09 \pm 0.3 \\
9 *\end{array}$ & $\begin{array}{l}3.06 \pm 0.2 \\
6 *\end{array}$ & $\begin{array}{l}3.01 \pm 0.1 \\
8^{*}\end{array}$ & $\begin{array}{l}3.04 \pm 0.1 \\
1 *\end{array}$ & $\begin{array}{l}1.96 \pm 1 . \\
44\end{array}$ & $\begin{array}{l}2.5 \pm 1.1 \\
4\end{array}$ & $\begin{array}{l}2.04 \pm 0 . \\
40\end{array}$ & $\begin{array}{l}1.07 \pm 0.1 \\
2\end{array}$ \\
\hline $\begin{array}{l}\text { Monocytes } \\
\text { Mean } \pm \text { SD }\end{array}$ & $\begin{array}{l}0.3 \pm 0.0 \\
4\end{array}$ & $\begin{array}{l}0.37 \pm 0.1 \\
1\end{array}$ & $\begin{array}{l}0.27 \pm 0.0 \\
5\end{array}$ & $\begin{array}{l}0.31 \pm 0.0 \\
7\end{array}$ & $\begin{array}{l}0.26 \pm 0.0 \\
4\end{array}$ & $\begin{array}{l}0.31 \pm 0.0 \\
3\end{array}$ & $\begin{array}{l}1.35 \pm 0 . \\
72\end{array}$ & $\begin{array}{l}0.23 \pm 0 . \\
06\end{array}$ & $\begin{array}{l}0.28 \pm 0 . \\
07\end{array}$ & $\begin{array}{l}0.28 \pm 0.0 \\
7\end{array}$ \\
\hline
\end{tabular}

*Significant increase $\mathrm{P}<0.05$

\section{Estimate the concentration of complement proteins $\mathrm{C3}$ and $\mathrm{C} 4$ :-}

The current results demonstrated the existence not significant differences in the concentration of C3 between normal immune system patients with skin infected $107.2 \mathrm{mg} / \mathrm{dl}$ and non-infected $117.76 \mathrm{mg} / \mathrm{dl}$, while there was a significant decrease in the concentration of this protein in immunodeficiency patients with a skin infection (diabetes 75.21 and kidney failure 65.39 and burns 42.37) $\mathrm{mg} / \mathrm{dl}$ and non- infected (diabetes 78.06 and kidney failure 91.81 and burns $59.44 \mathrm{mg} / \mathrm{dl}$ ) compared to control, while there was significantly rise in cancer patients with skin infection $209.91 \mathrm{mg} / \mathrm{dl}$ and in non- infected $190.69 \mathrm{mg} / \mathrm{dl}$ compared to the other studied groups as shown in figure 1 . 


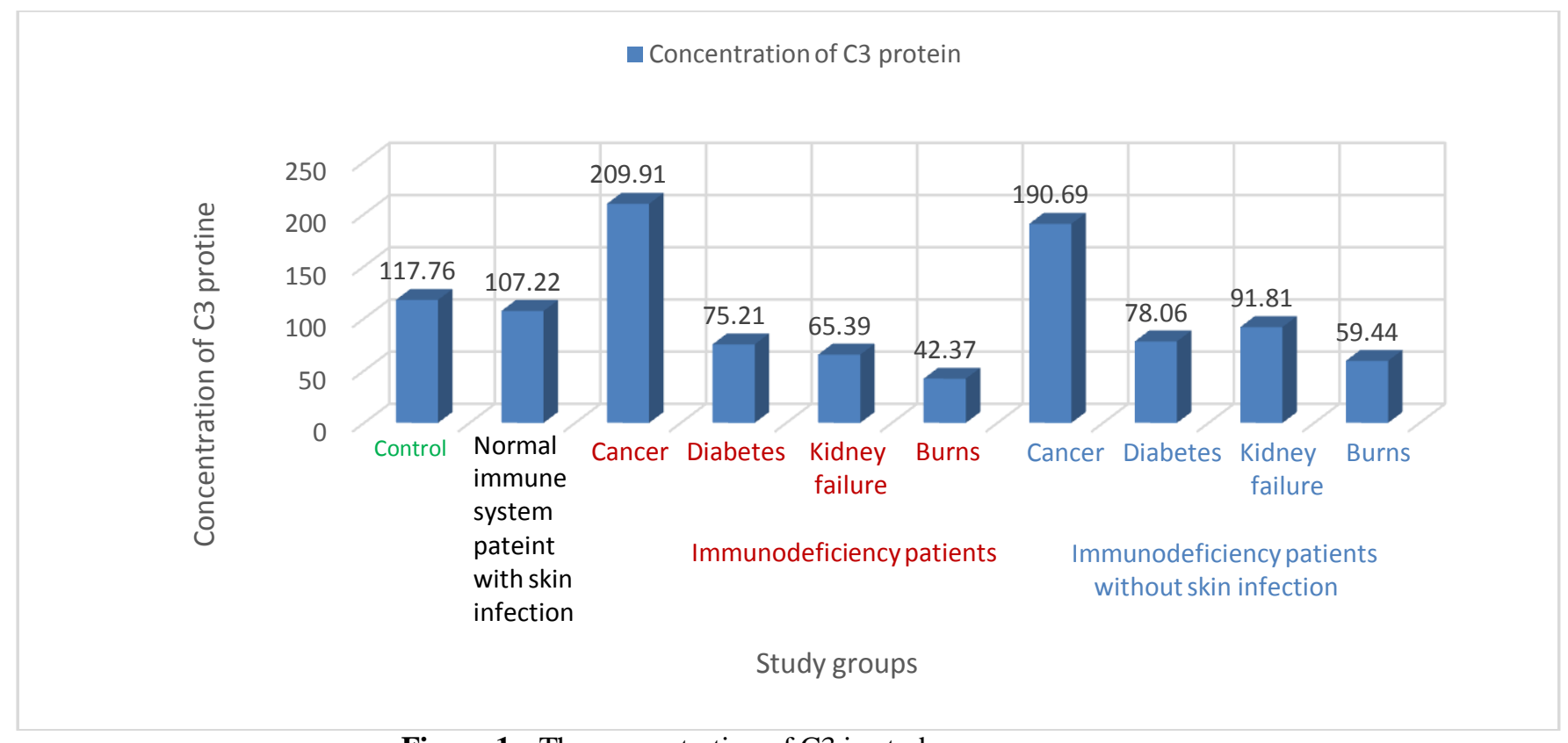

Figure 1:- The concentration of $\mathrm{C} 3$ in study groups.

The result show in figure (2) explain high significant in $\mathrm{C} 4$ concentration in patients with normal immune system \& a skin infected $(49.49 \mathrm{mg} / \mathrm{dl})$ compared to the control $(30.81 \mathrm{mg} / \mathrm{dl})$ while there were no significant differences on the level of this protein in immunodeficiency patients with a skin infection (cancer $39.5 \mathrm{mg} / \mathrm{dl}$, kidney failure23.96 mg / dl and burns $30.89 \mathrm{mg} / \mathrm{dl}$ ) but in immunodeficiency patients without a skin infection reaching the protein concentration to $24.97 \mathrm{mg} / \mathrm{dl}$ cancer and $27.58 \mathrm{mg} / \mathrm{dl}$ kidney failure but reached to 31.77 $\mathrm{mg} / \mathrm{dl}$ in burns, except diabetic patients who appeared to have a high significant rate $(53.5 \mathrm{mg} / \mathrm{dl})$ when there are skin injuries but reached to $26.16 \mathrm{mg} / \mathrm{dl}$ when there are no-skin infection .

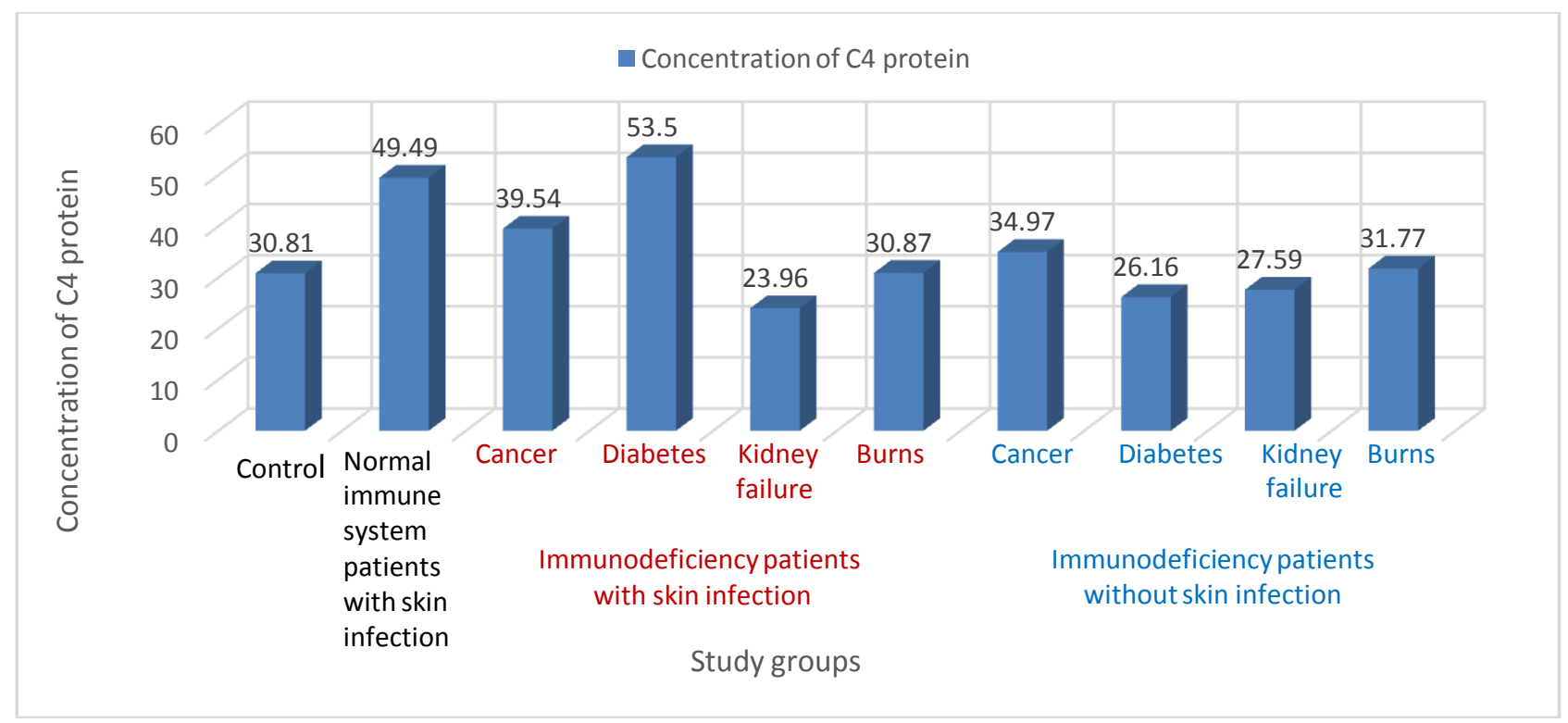

Figure 2:- The concentration of $\mathrm{C} 4$ protein in study groups.

Believes that the reason for the change in the concentration of $\mathrm{C} 3$ protein may be due to the activation of the classical pathway which lead to divided $\mathrm{C} 3$ to $\mathrm{C} 3 \mathrm{a} \& \mathrm{C} 3 \mathrm{~b}$ and thus lower serum concentration of the original protein C3 (Lendrum et al.,1976). In addition to that high blood sugar leads to the weakening of many mechanisms 
in the humoral defenses mechanism in addition to linking glucose to chemically active site of C3 which prevents linking the protein to the surface of microbes and thus prevent the opsonization process (Vergani et al.,1983; Hoster, 1990).

The antigens of cancer cells usually stimulate a production of antibodies in blood stream of patient where those are able to play a protective role for the elimination of tumors through variety of mechanisms such as associated with antigen and formation immune complex that has ability to activates the complement system and formation Membrane attack complex (MAC) (Kuby,1993) so complement proteins continue to rise as long as the prescience of tumors in the body, which act as stimulator for the continued production of antibody (Verhaegen et al.,1976; Carli et al., 1979).

In general, the activated complement a very useful system to the host, but activated in patients who are exposed to injuries after wounds or burns lead to the consumption and depletion of the basic elements of complement and low C3 and C4 levels and weaken the functions required for chemotactic and opsonization, thus delay the decomposition of microbial cell that occurs in acute bacterial infection such as those that occur in the post-burn (Brown et al., 2002).

Estimate the level of Interleukin 33 (IL-33):-

The results shown in the figure (3) indicate that a significant increase in the concentration of IL- 33 in the immunodeficiency patients with a skin infection reaching cancer $210.86 \mathrm{pg} / \mathrm{ml}$, diabetes $422.01 \mathrm{pg} / \mathrm{ml}$, kidney failure $374.25 \mathrm{pg} / \mathrm{ml}$ and burns $297.26 \mathrm{pg} / \mathrm{ml}$ when compared with immunodeficiency patients only (cancer patients $197.9 \mathrm{pg} / \mathrm{ml}$, diabetes $292.76 \mathrm{pg} / \mathrm{ml}$, kidney failure $211.66 \mathrm{pg} / \mathrm{ml}$ and burns $219.06 \mathrm{pg} / \mathrm{ml}$ ) and normal immune system patient with skin infections $192.5 \mathrm{pg} / \mathrm{ml}$ and control $160.3 \mathrm{pg} / \mathrm{ml}$, where noted that the level of cytokine was higher for patients with diabetes and renal failure with a skin infection, also noted there was high among normal immune system patients with skin infections $192.5 \mathrm{pg} / \mathrm{ml}$ compared with a range of control 160.3 $\mathrm{pg} / \mathrm{ml}$. The reason for this change in level of interlukin 33 due to being one of the interleukin-1 family that increase their rates during immunosupration cases, inflammation and various infections. Where microbial infections induce macrophage cells to release several inflammatory mediators such as IL-1 and IL-12 and TNF- $\alpha$ and other types of pro-inflammatory cytokine including the IL-33 and considered these inflammatory mediators are essential enhancement for the body to respond to different infections and thus will increase the blood flow locally and increasing numbers of white blood cells and attracted neutrophil cells to the affected area to kill the bacteria (Munford and Pugin,2001). The IL-33 production usually associated with chronic inflammation cause therefore the high level of this cytokine in patient serum regarded as marker for development inflammation because the begin of inflammation and cell damage because its release from infected cells and thus works to alert the immune system to the set of injury (Saenz et al., Nile et al., 2010).In addition high level of this cytokine play important role in healing or treatment of epithelial and mucosal layers (Palmer et al., 2009). 


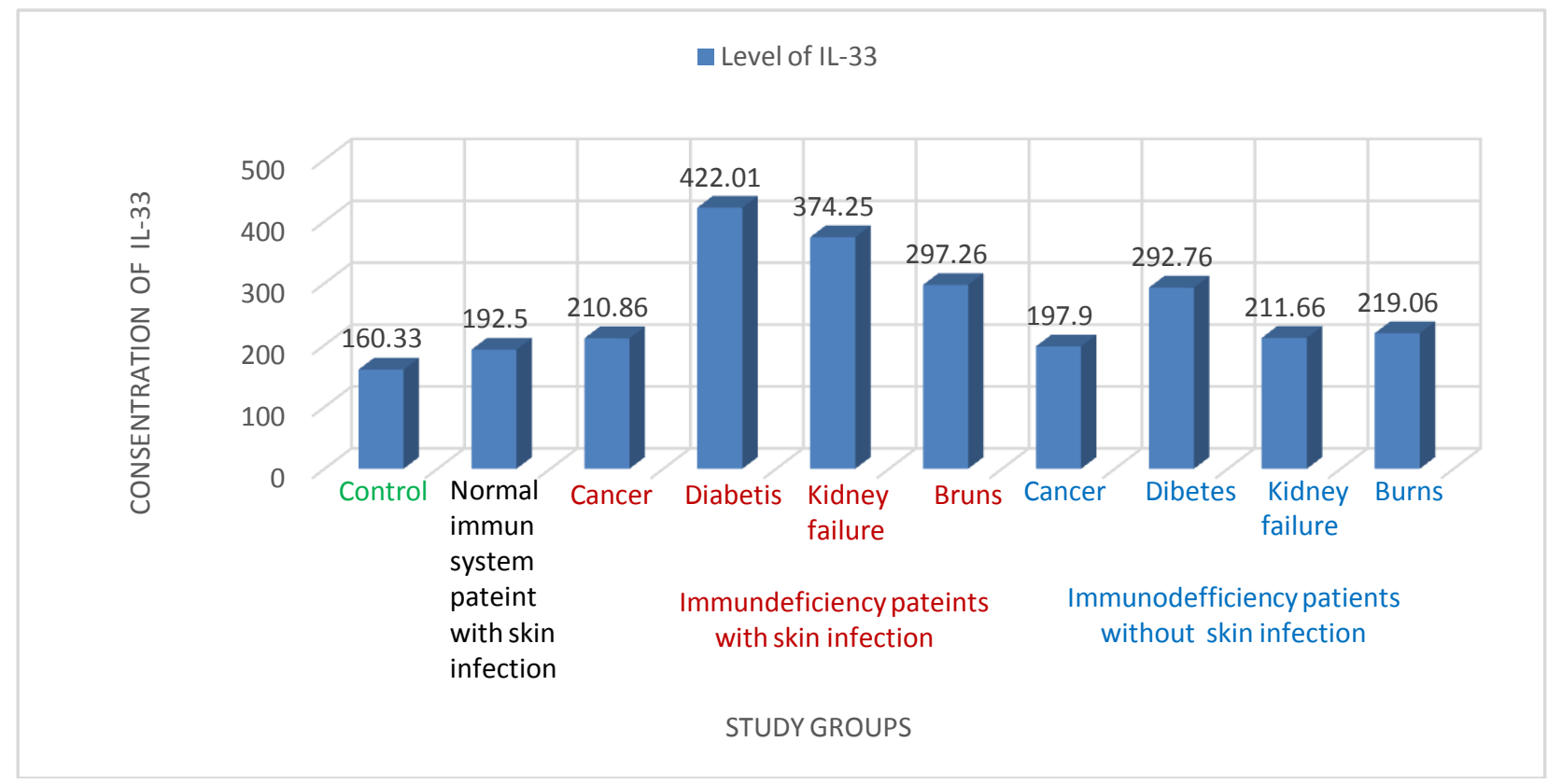

Figure 3:- The level of IL-33 in study groups.

Estimate the level of Interleukin 27 (IL-27):-

The results shown in the figure (4) refer that there is a clear significant decrease in the concentration of IL-27 in the study groups as compared with control as well as showing that there is a significant increase in the concentration of this factor among immunodeficiency patients with a skin infection (cancer patients $87.1 \mathrm{pg} / \mathrm{ml}$, diabetes $79.05 \mathrm{pg}$ $/ \mathrm{ml}$, renal failure $78.41 \mathrm{pg} / \mathrm{ml}$ and burns $54.76 \mathrm{pg} / \mathrm{ml}$ compared with immunodeficiency patients without a skin infection (cancer patients $81.02 \mathrm{pg} / \mathrm{ml}$ and diabetes $51.22 \mathrm{pg} / \mathrm{ml}$ and kidney failure $60.6 \mathrm{pg} / \mathrm{ml}$ burns $67.68 \mathrm{pg} /$ $\mathrm{ml}$ ) although this cytokine rate significantly decreased in those two groups when compared with normal immune system with skin infection ( $115.1 \mathrm{pg} / \mathrm{ml}$ ) thing who also appeared at normal immune system patients with skin infection ( $69.62 \mathrm{pg} / \mathrm{ml}$ ) when the compared to control.

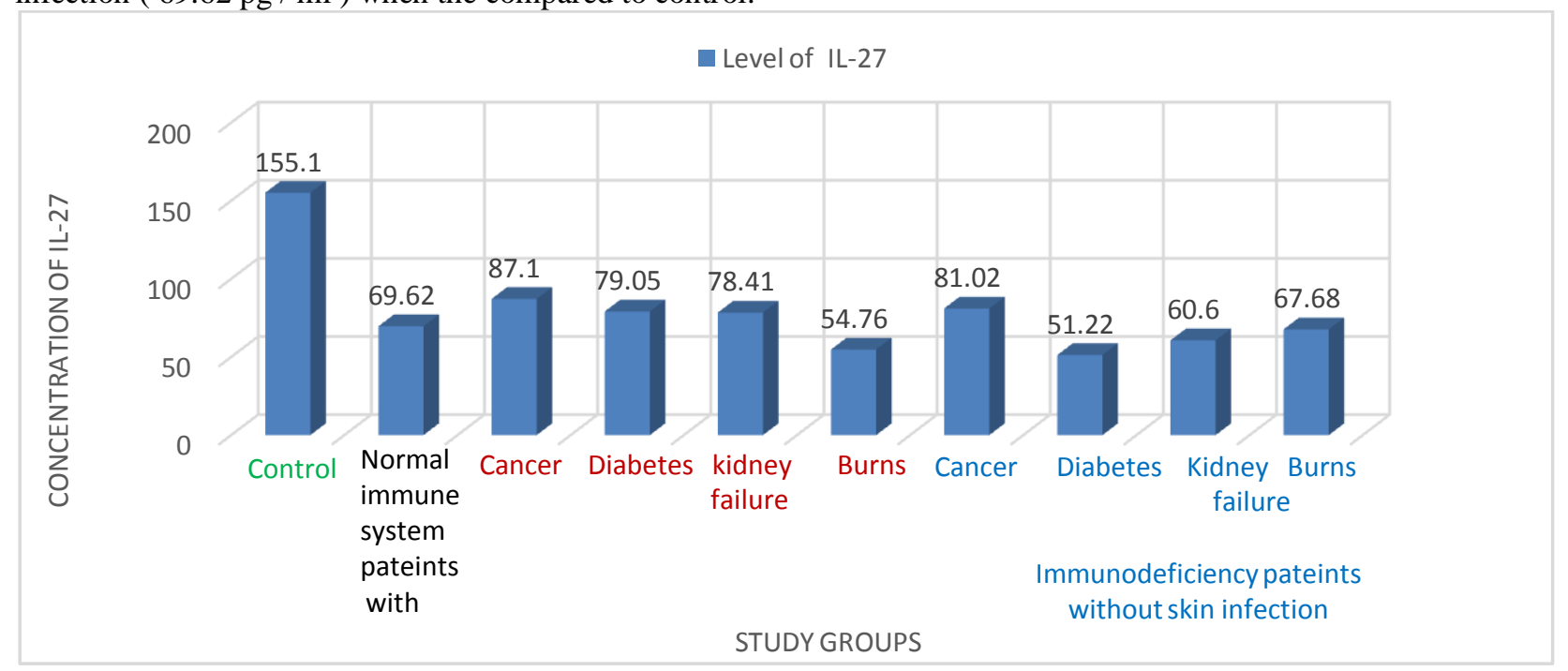

Figure 4:- The level of IL-27 in study groups .

when comparing the rate of decline between the studies groups appeared a clearly that patients with burns were the most increase where it is believed that these few percentage of IL-27 are of particular importance to prevent further inflammation, especially in the severe cases. While in other immunodeficient patients note there are a 
slight increase in the case of the presence of infections in these patients where the immune system is more harmful and the injuries were life-threatening while in the immunodeficiency patients only the diabetic patients are the most low, where the reason for this is that increasing the level of IL-27 may causes exacerbation of diabetes through stimulating the T-lymphocyte and innate immune response that responsible to produce cytokines that may causes break down pancreatic beta cells that responsible to secrete insulin. The continues treatment of diabetes patient may helped to reduce the proportion of sugar and level of IL-27 but notes that the level of IL-27 will rise against in patients with diabetic foot because bacterial infection (Santos et al., 2013).IL-27 play an important role in the innate and adaptive immune response and characterized by the pro and anti-inflammatory cytokine properties. It also works in collaborate with IL-12 to promote the spread of CD4T- Cell, which, confirms his work as pro-inflammatory cytokine (Pflanz et al., 2002; Hall et al., 2012).

\section{Estimate the concentration of Tumor necrosis factor- $\alpha$ (TNF- $\alpha)$ :-}

The current results illustrated significant increase in the level of TNF- $\alpha$ concentration in the serum of all patients compared with control $(155.26 \mathrm{pg} / \mathrm{ml})$ where the rise in all of the immunodeficiency patients such as of the cancer patients $218.9 \mathrm{pg} / \mathrm{ml}$, diabetes $266.2 \mathrm{pg} / \mathrm{ml}$,failure renal $219.9 \mathrm{pg} / \mathrm{ml}$ and burns $333.8 \mathrm{pg} / \mathrm{ml}$ as well as in the immunodeficiency patients with skin infection, the burns patients were the highest of TNF- $\alpha$ level $(385.3 \mathrm{pg} / \mathrm{ml})$ followed by renal failure patients $(295.3 \mathrm{pg} / \mathrm{ml})$, diabetes $(249.4 \mathrm{pg} / \mathrm{ml})$ and cancer $(215.5 \mathrm{pg} / \mathrm{ml})$. While normal immune system patients with skin infection explain not significant increase in TNF rate ( $176.1 \mathrm{pg} / \mathrm{ml})$ compared with control( $155.26 \mathrm{pg} / \mathrm{ml})$ as shown in figure (5).

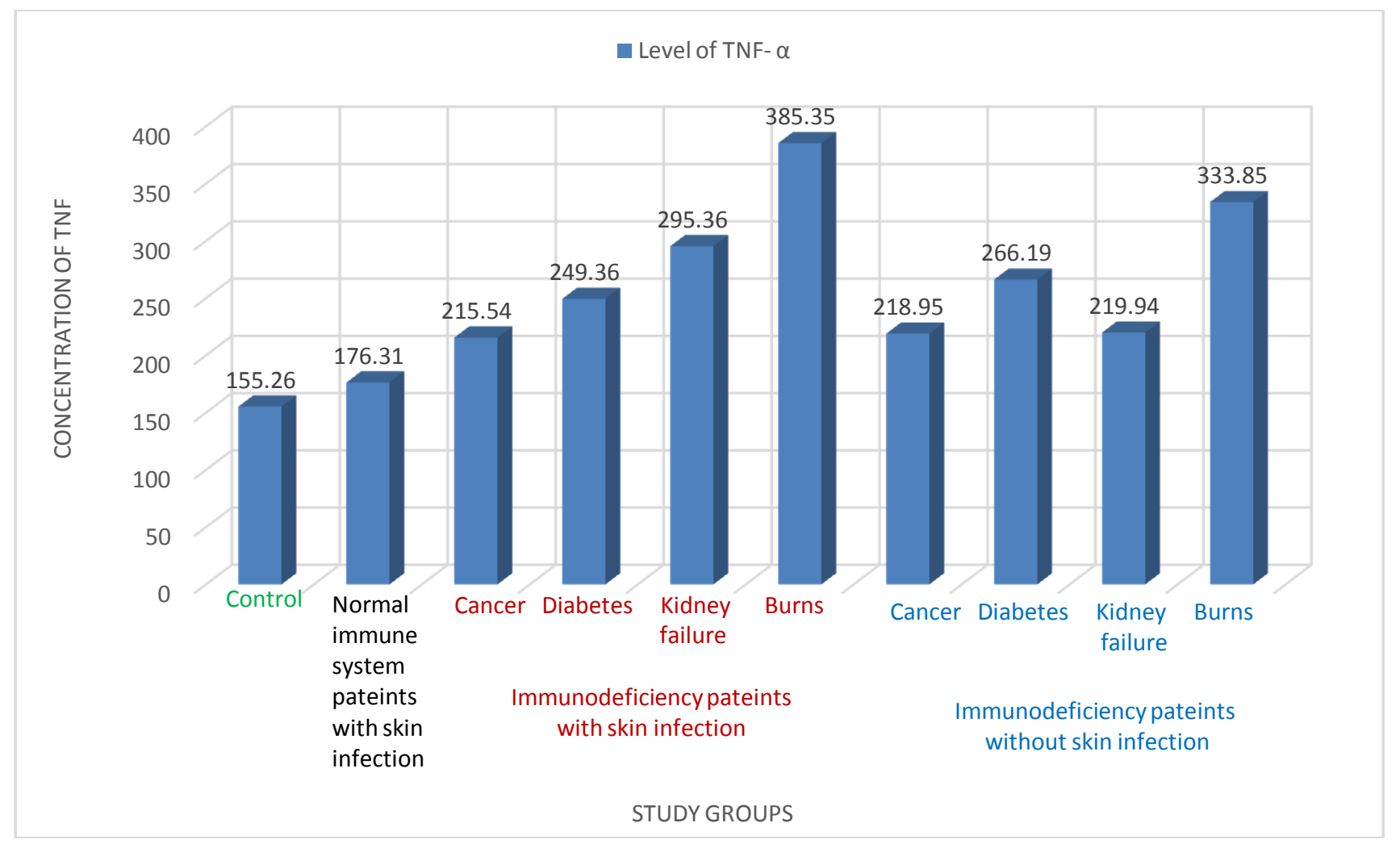

Figure 5:- The level of TNF- $\alpha$ in study groups.

The TNF- $\alpha$ is pro-inflammatory cytokines which is secreted from lymphocytes and other cells in many acute and chronic inflammatory diseases it is likely to active those disease linked to secrete cytokine that leading to inflammation through direct activation of monocytes cells (Evans et al., 1998). It also a factor to activating the body response and produce other cytokine through infection where he plays important role in the inflammatory response to burn and wound (Santos et al., 2013). There is a correlation between clinical stage of cancer and the 
serum levels of TNF- $\alpha$ because the numbers of cells that produce the TNF- $\alpha$ increase in the progress of tumors and the level of TNF- $\alpha$ increase with progresses tumor in addition the presence of high level from TNF many destroy \&prevent the spread of cancer cells (Konukogl and Turhan,2005)

When the level of TNF- $\alpha$ increase in serum of patient with renal failure may causes the apoptosis of renal cells (Varfolomeev and Ashkenazi, 2004) some studies have pointed to the role played by TNF- $\alpha$ in the pathogenesis of diabetic patients through its interaction with the insulin transport routs (Yeo et al., 2010).

\section{References:-}

1. Baron, E. J. and Finegold, S. M. (1990). Diagnostic Microbiology. 8th ed. The C. V. Mosby Company, Baltimore.

2. Biffl , W.; Moore , E.; Moore , F .; Frederich , A. and Peterson , V. (1996) . Interleukin-6 in the injured patient, marker of injury or mediater of inflammation . Annals of surgery . 224 (5) : 647-664.

3. Brooks, M. L. (2008). Exploring Medical Language: A Student-Directed Approach, 7th Edition. St. Louis, Missouri, USA: Mosby Elsevier. PP: 398.

4. Brown, J.S.; Hussell, T.; Gilliland ,S.M.; Holden, D.W.; Paton, J.C.; Ehrenstein, M.R, et al,.(2002). The classical pathway is the dominant complement pathway required for innate immunity to Streptococcus pneumoniae infection in mice. Proc. Natl .Acad. Sci. U S A.99:16969-74.

5. Buckley, R. H. (2000). Primary immunodeficiency diseases due to defects in lymphocytes. New England Journal of Medicine. 343(18): 1313-1324.

6. Carli, M.; Bucolo, C. ; Pannunzio, M.T. and Ongaro, G. (1979). Fluctuation of serum complements level in children with neuroblastoma. Cancer. 43:2399-2404.

7. Chung, S.; Liu, X.; Macias, A. and Baron, R.M. (2008). Heme oxygenase -1- derived carbon monoxide enhance the host defence response to microbial sepsis in mice . J. Clin. Invest.118(1): 239-247.

8. Collee, J.G.; Fraser, A.G.; Mjarmion , B.P. and Simmons, A. (1996). Mackie and McCartney paractical medical microbiology .( $14^{\text {th }}$ ed.) Chrchill. Livingston . USA.

9. Douwes, J.; Gibson, P.; Pekkanen, J. and Pearce, N. (2002). Non-eosinophilic asthma: importance and possible mechanisms. Thorax, 57: 643-648.

10. Ennis, M.(2006). Neutrophils in asthma path physiology. Curr. Allergy Asthma Rep., 3(2): 159-165.

11. Evans, C.A.; Jellis, J. ; Hughes, S.P.; Remick, D.G.; Friedland, J.S. (1998).Tumor necrosis factoralpha, interleukin-6, andinterleukin-8 secretion and the acute-phase response in patients with bacterial and tuberculosis osteomyelitis.J .Infect . Dis. 177: 1582-1587.

12. Hall, A.O; Silver J.S.and Hunter,C.A.( 2012).The immunobiology of IL-27.Adv. Immunol. 115:1-44.

13. Hoster, M.K. (1990). Handicaps to host defense. Effects of hyperglycemia on C3 and cardio albicans. Diabetes, 39: 271-275.

14. House, R. V. and Descotes, J.(2007). Cytokines in Human Health Immunotoxicology, Pathology,and Therapeutic Applications .

15. Jawetz,E.; Brook,G.F.;Butel,J.S. and Morse, S.A.(1998). JawetsMelnik and Adelberges Medical Microbiology. $21^{\text {st }}$ ed. Appelton \& Lange,California, :197-203.

16. Konukoğlu, D.; Turhan ,S.M.( 2005).Molecular basis of angiogenesis mechanisms and tumor angiogenesis. Cerrahpaşa. J .Med. 36: 42-48.

17. Kuby,J.(1993).Immunology. Complement System 15. W.H. Freeman Company: 585.95.

18. Lendrum, R.; Walker, G.; Cudworth, A.G. et al. (1976). Islet cell antibodies in diabetes mellitus. Lancet. $1273-6$.

19. Liu, L.; Roberts, A. and Ganz, T. (2003) . By IL-1 signaling, monocyte- derived cells dramatically enhance the epidermal antimicrobial response to lipopolysaceharide . J. of Immunol. 170: 575-580.

20. Mancini, G.; Carbonara, A.O. and Hermans, J.F. (1965).Immunochemical quantization of antigen by single radial immunodiffusion. Immunochemistry.2:235-254.

21. Munford, R.S. and Pugin, J. (2001). Normel responses to injury prevent systemic inflammation and can be immunosuppresive . Am. J. Respir. Crit. Care Med. 163(2): 316-321.

22. Nile, C.J.; Barksby,E.; Jitprasertwong ,P.;Preshaw, P.M.and Taylor, J.J.(2010). Expression and regulation of interleukin-33 in humanmonocytes. Immunology; 30:172-180.

23. Ozumba,U.C. and Jiburum, B.C.(2000). Bacteriology of burn wounds in Enugu, Nigeria. Burns,Mar, 26(2): 178-80.

24. Palmer, G.;Talabot-Ayer, D.; Lamacchia, C. et al. (2009). Inhibition of interleukin -33 signaling attenuates the severity of experimental arthritis.Arthritis Rheum., 60:738-49. 
25. Pflanz, S.; Timans, J. C.; Cheung, J.; Rosales, R.; Kanzler, H.;Gilbert, J.;Hibbert, L. ; Churakova, T.; Travis,M.;Vaisberg, E.; Blumenschein, W. M.; Mattson, J. D.; Wagner, J. L.; To, W.; Zurawski, S.; McClanahan, T. K.; Gorman, D. M.; Bazan, J. F.; de-Waal-Malefyt, R.; Rennick, D. and Kastelein, R. A. (2002) .IL-27, a heterodimeric cytokine composed of EBI3 and p28 protein, induces proliferation of naive CD4(+) T cells. Immunity.16 (6): 779-790.

26. Roitt, I.M.\& Rabson,A. (2000). Really essential medical immunology. Black well Sci., Oxford: 186-190.

27. Saenz, S.A.; Taylor, B.C.; Artis, D. (2008). Welcome to the neighborhood: Epithelial cell-derived cytokines license innate and adaptive immune responses at mucosal sites.Immunol. Rev., 226:172-190.

28. Sanin,D.E.;Prendergast,C.T.;Bourke,C.D.andMountford,A.P.(2015).Helminth Infection and Commensal Microbiota Drive Early IL-10 Production in the Skin by CD4+T Cells That Are Functionally Suppressive.PLoS Pathog 11(5): 1-23.

29. Santos, A.S.; Melo, M.E.; Crisóstomo, L.G.; Fukui ,R.T.; Matioli, S.R.and Silva, M.E.(2013). Lack of association between IL27 gene variants and type 1 diabetes susceptibility. Elsevier.Ltd.61 (2):349-52.

30. Senna, P.M.; da,S.W.J.and Cury, A.A. (2012). Denture disinfection by microwave energy: Influence of Candida albicans biofilm. Gerodontology .29: 186-191.

31. Todar, K. (2002). Pseudomonas aeruginosa . J. of Bacteriol.22(6):330- 355.

32. Varfolomeev,E.E. and Ashkenazi,Z.( 2004).Tumor necrosis factor: an apoptosis Cell. 20.116(4):491-7.

33. Vergani, D., Johnston: Abdullah, N.B. and Barnett, A.H.(1983). Low Serum concentration: an inherited predis position to insulin dependent diabetes. Br. J. Med. 286.

34. Verhaegen, H.; De Cock, W.;De Cree, J. and Verbruggen, F.(1976). Increase of serum complement levels in cancer patients' with progressing tumors. Cancer, 38:1608-1620.

35. Vihinen.M.(2005). Immunodeficiency, Primary: Affecting the Adaptive Immune System. Encychopedia of life sciences:1-6.

36. Xu ,W.; Wu, H.f.; Ma,S.G.; Bai,F.; Hu,W.; Jin,Y.andLiu,H.(2013).Correlation between Peripheral White Blood Cell Counts and Hyperglycemic Emergencies. Int. J. Med. Sci., 10(6):758-765.

37. Yang,Y.L.( 2003). Virulence factors of Candida species. J. Microbiol. Immunol . Infect. Dec.36(4):223-8.

38. Yeo,E.S,; Hwang .J.Y; Park .J. E.,; Choi .Y. J,; Huh .K. B, and Kim W.Y. (2010).Tumor Necrosis Factor (TNF- $\alpha$ ) and C-reactive Protein(CRP) are Positively Associated with the Risk of Chronic KidneyDisease in Patients with Type 2 Diabetes. Yonsei .Med .J.51(4):519-525.

39. Yoshida ,H.; Nakaya, M. and Miyazaki , Y. (2009). "Interleukin 27: adouble-edgedswordforoffense and defense," Journal of Leukocyte Biology,.86 (6):1295-1303. 